\title{
Corrosion Resistance of Electroless Ni-B-W-Mo Coatings Using Electrochemical Impedance Spectroscopy
}

\author{
Arkadeb Mukhopadhyay, Tapan K. Barman and Prasanta Sahoo * \\ Department of Mechanical Engineering, Jadavpur University, Kolkata, India
}

Received August 1, 2017; accepted January 25, 2018

\begin{abstract}
Quaternary Ni-B-W-Mo coatings were deposited on AISI 1040 steel by the electroless method. Some of the specimens were heat-treated at $300,350,400,450$ and $500{ }^{\circ} \mathrm{C}$, for 1 hour. The deposited coatings contained a high weight percentage of $\mathrm{W}$, and a low $\mathrm{B}$ content was detected by energy dispersive X-ray analysis. The coatings in as-deposited state were amorphous, and heat treatment resulted in crystallization with the precipitation of borides. $\mathrm{W}$ and Mo were present in the coatings, mainly in a solid solution form. The surface morphology study revealed densely nodulated structures, which are pertinent for sodium borohydride reduced electroless nickel coatings. Electrochemical impedance spectroscopy studies were conducted to determine the corrosion resistance of the as-deposited and heat-treated coatings in a $3.5 \% \mathrm{NaCl}$ electrolyte. The corroded surfaces were observed under scanning electron microscope, to study the corrosion mechanism.
\end{abstract}

Keywords: electroless nickel; Ni-B-W-Mo; coating and corrosion resistance.

\section{Introduction}

Sodium borohydride reduced electroless nickel (EN) (Ni-B) coatings are potential candidates as anti-wear and anti-friction agents in industrial applications under demanding conditions [1]. They possess high hardness, and their surface morphology, along with columnar growths, imparts self lubricating properties to the coatings [2]. In fact, these alloy coatings have higher hardness than those obtained from hypophosphite based baths in as-plated conditions [3]. The columnar growth of Ni-B coatings reduces their actual area of contact, and acts as a pocket for retaining lubricants [4]. The mechanical and wear properties are further enhanced during heat treatment, due to the precipitation of hard boride phases [5]. Thermochemical treatment/nitriding and vacuum heat treatment have a positive effect on the coating properties [6-8]. Due to such excellent properties, Ni-B coatings are increasingly replacing chromium, due to their favorable environmental impacts. Recent studies indicate the superior microhardness, thermal stability, low wear rate and friction coefficient of ternary electroless

\footnotetext{
* Corresponding author. E-mail address: psjume@gmail.com
} 
alloy coatings obtained from a borohydride reduced bath [3]. Even higher microhardness and wear resistance are achieved by the co-deposition of composite particles such as $\mathrm{TiO}_{2}, \mathrm{Al}_{2} \mathrm{O}_{3}$ and $\mathrm{SiC}$ [9-11].

Apart from the excellent mechanical and tribological properties, borohydride reduced coatings provide corrosion resistance, and protect the substrate from corrosive attacks. Electroless Ni-B coatings provide effective corrosion resistance to $316 \mathrm{~L}$ stainless steel, commercially pure titanium, magnesium and AZ91D alloys [4, 5, 12]. Heat treatment of Ni-B coatings leads to deterioration in the corrosion resistance, due to the formation of new phases and grain boundaries which form active sites of corrosion attack [13]. Coatings with a low boron content are more prone to corrosive attacks [14], in comparison to those with a high boron content [13]. The coating bath temperature also significantly affects the Ni-B coatings corrosion resistance. Ni-B coatings coated at a $60{ }^{\circ} \mathrm{C}$ bath temperature have an excellent corrosion resistance [15]. Das and Sahoo [16] obtained optimal coating bath parameters for achieving enhanced corrosion resistance of Ni-B coatings, using Taguchi's orthogonal array and grey relational analysis. Improvement in the corrosion resistance of $\mathrm{Ni}$-B coatings could be also achieved by thermochemical treatments [6]. Inclusion of tungsten/molybdenum or co-deposition of composite particles also lead to an improvement in corrosion resistance [9-11, 17-18]. Nevertheless, hypophosphite reduced coatings are still more prone to corrosion resistance and prevention from chemical attacks, compared to borohydride reduced alloy/ poly alloy or composite coatings $[1,19]$. Although several research works report the properties of the binary Ni-B, ternary $\mathrm{Ni}-\mathrm{B}-\mathrm{W}$ and Ni-B-Mo, and composite variants of sodium borohydride reduced coatings, the deposition and corrosion characteristics of the quaternary variant yet remain unexplored. The present work aimed to carry out the Ni-B-W-Mo coating deposition by the electroless method, and observe the effect of heat treatment on its morphological, structural and corrosion resistance. W and Mo were selected as alloying elements, since it was observed that they improve the thermal stability, oxidation resistance, tribological behavior and corrosion resistance of Ni-B coatings [2, 3, 17,18]. Therefore, the inclusion of both $\mathrm{W}$ and Mo may lead to superior properties, and further open the Ni-B coatings scope of improvement. Electroless Ni-B-W-Mo coatings were deposited on AISI 1040 steel specimens. The coatings were heat-treated at $300-500{ }^{\circ} \mathrm{C}$, for 1 hour. The composition, morphological and structural properties of as-deposited and heattreated coatings were observed using energy dispersive X-ray analysis, scanning electron microscope and X-ray diffraction techniques. The corrosion characteristics of the as-deposited and heat-treated coatings were observed using electrochemical impedance spectroscopy.

\section{Experimental details}

Electroless Ni-B-W-Mo coatings were deposited on AISI 1040 steel specimens $(15 \times 15 \times 2 \mathrm{~mm})$ of $\mathrm{N} 5\left(\mathrm{R}_{\mathrm{a}}=0.4 \mu \mathrm{m}\right)$ roughness grade. The substrates were chosen, since EN coatings follow the substrate profile. Initially, the specimens were thoroughly cleaned in detergent water, followed by acetone degreasing and 
rinsing in deionized water. The substrates were then air dried and subjected to pickling treatment in a $50 \% \mathrm{HCl}$ solution for $1 \mathrm{~min}$. The specimens were again rinsed in deionized water, and finally immersed into the electroless bath. Sodium tungstate $(12.5 \mathrm{~g} / \mathrm{L})$ and sodium molybdate $(12.5 \mathrm{~g} / \mathrm{L})$ were used as the $\mathrm{W}$ and Mo source, in the borohydride reduced alkaline electroless bath mentioned in the study by Mukhopadhyay et al. [3], where the coating bath details and operating conditions may be found. A double bath coating system was adopted and, after 2 hours of deposition, the old bath was replaced by a new one. After a total period of 4 hours of deposition, the specimens were withdrawn from the bath, and rinsed in deionized water. Some coated specimens were subjected to heat treatment at $300,350,400,450$ and $500{ }^{\circ} \mathrm{C}$, for 1 hour, in a muffle furnace.

The coating composition in as-deposited state was determined using an energy dispersive X-ray (EDX) analyzer equipped with a $\mathrm{Si}(\mathrm{Li})$ super ultra thin window (SUTW) for the transmission of low energy X-rays. The surface morphology of the as-deposited and heat treated coatings was observed under high vacuum, using a scanning electron microscope (SEM) with an Everhardt Thornley secondary electron detector (FEI QUANTA FEG 250). Phase structures of the coating in as-deposited and post heat treatment conditions were identified using $\mathrm{X}$-ray diffraction (XRD) technique, by employing $\mathrm{Cu} \mathrm{K} \alpha$ radiation, at a scan rate of $1^{\circ} / \mathrm{min}$ and $2 \theta^{\circ}$, ranging from 20 to $80^{\circ}$ (Rigaku, Ultima III).

The coatings corrosion resistance was studied by electrochemical impedance spectroscopy (EIS), using a potentiostat (Gill AC, ACM instruments, UK) and a three electrodes arrangement electrochemical cell, with $3.5 \% \mathrm{NaCl}$ as electrolyte. The coated specimen acted as working electrode (WE), a platinum electrode served as auxiliary electrode (AE), and a saturated calomel electrode was used as reference electrode (RE). The arrangement was such that only $1 \mathrm{~cm}^{2}$ of the coated specimen surface was exposed to the electrolyte. The applied frequencies during the EIS tests varied from $10 \mathrm{kHz}$ to $0.01 \mathrm{~Hz}$. The equivalent circuit to fit the EIS parameters is shown in Fig. 1.

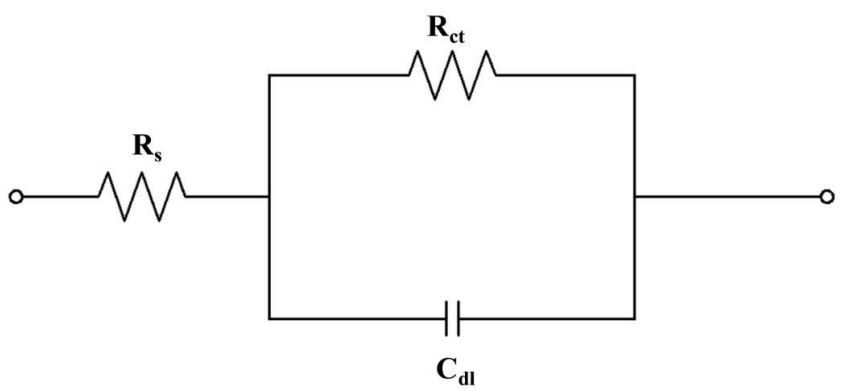

Figure 1. Equivalent circuit of EIS.

The charge transfer resistance $\left(\mathrm{R}_{\mathrm{ct}}\right)$ is the electron transfer resistance during the electrochemical reactions, while double layer capacitance $\left(\mathrm{C}_{\mathrm{dl}}\right)$ is associated with the coatings delamination. The resistance offered between WE and RE is denoted by the solution resistance $\left(R_{s}\right) . R_{c t}$ and $C_{d l}$ values are considered as the corrosion parameters, and were obtained from Nyquist plots by fitting a semi-circle, using dedicated software provided by the instrument setup. After the corrosion tests, 
some specimens were observed under SEM (JEOL, JSM 6360), to ascertain the corrosion mechanism.

\section{Results and discussions}

\section{Coating composition}

The composition of the as-deposited coatings was obtained using EDX, and the spectrum is shown in Fig. 2. The percentage by weight of $\mathrm{Ni}, \mathrm{B}, \mathrm{W}$ and $\mathrm{Mo}$ is $78.8,3.2,15.7$ and $2.3 \%$, respectively. It may be noted that $\mathrm{W}$ deposition in the obtained quaternary coating is quite high, in comparison to the Ni-B-W coating, where a higher amount of sodium tungstate $(25 \mathrm{~g} / \mathrm{L})$ has been used [3]. This could be due to the presence of sodium molybdate, which has a stabilizing effect on EN baths [20], and aids $\mathrm{W}$ deposition. The B content is seen to be in the low$\mathrm{B}$ range, and the coatings could be nanocrystalline [13-14]. In general, B's weight percentage deposited in Ni-B coatings influences its crystallinity, as well as the corrosion resistance. Coatings with higher B content are amorphous, and have a higher corrosion resistance [13], whereas low-B coatings are nanocrystalline, and have a low resistance to corrosion [14].

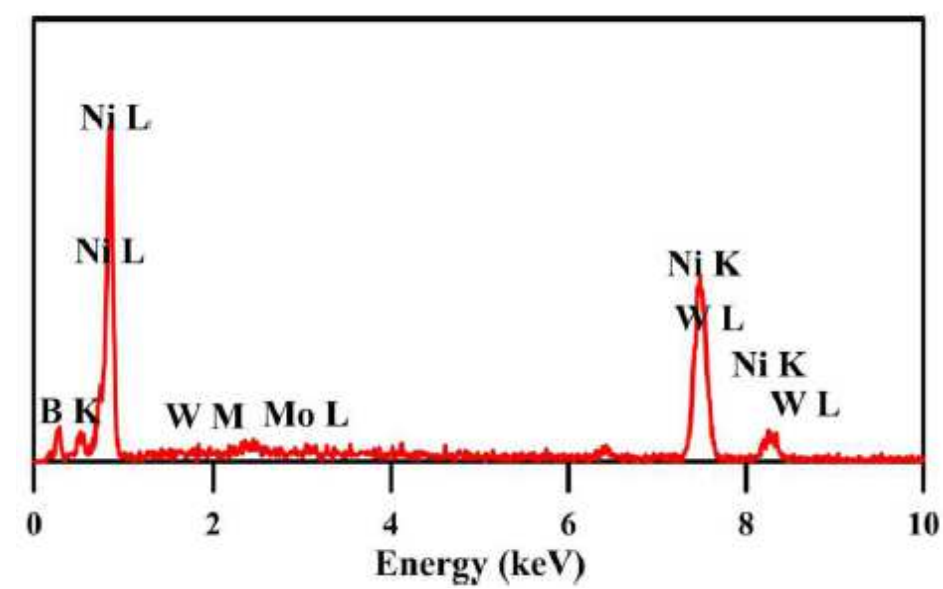

Figure 2. EDX analysis of as-deposited Ni-B-W-Mo coatings.

\section{Surface morphology}

The surface morphology of the as-deposited and heat-treated coatings is shown in Fig. 3. Well defined nodular structures similar to Ni-P-W-Mo coatings in asdeposited condition (Fig. 3(a)) were obtained. Such morphology, which makes borohydride reduced coatings naturally lubricious, has been referred to as cauliflower-like by several researchers [4-5].

On heat treatment, grain boundaries start to appear, indicating the crystallization onset (Fig. 3(b)-(f)). Such effect is more prominent for the coatings heat-treated at 450 and $500{ }^{\circ} \mathrm{C}$, for 1 hour, in Fig. 3(e) and Fig. 3(f), respectively. Inflated nodules for Ni-B coatings have been observed by Das and Sahoo [16], in comparison to the as-deposited ones. But, in the present work, such phenomenon was not observed, and only a slight inflation may be seen. This is possibly due to the high thermal stability of the coatings, resulting from $\mathrm{W}$ and $\mathrm{Mo}$ codeposition. The Ni-B-W-Mo coatings heat-treated at $500{ }^{\circ} \mathrm{C}$, for 1 hour, turned 
bluish, due to $\mathrm{Ni}$ oxides formation. A cross-cut section of the as-deposited coating is shown in Fig. 4. Coatings columnar growths may be clearly observed, and closely connected to the substrate with $\sim 30 \mu \mathrm{m}$ thickness. Two coating deposition phases may be demarcated in Fig. 4, resulting in a double layer coating. This is similar to the observation made by Vitry et al. [21], where the bath replenishment effect was investigated. Moreover, the typical columnar growths of Ni-B and its alloys have been observed in most of the studies, and agree well with the present observations [2-5, 22]. The columnar growths mainly act as a pocket for retaining lubricants, and decrease the actual contact area, resulting in low wear and friction coefficient.
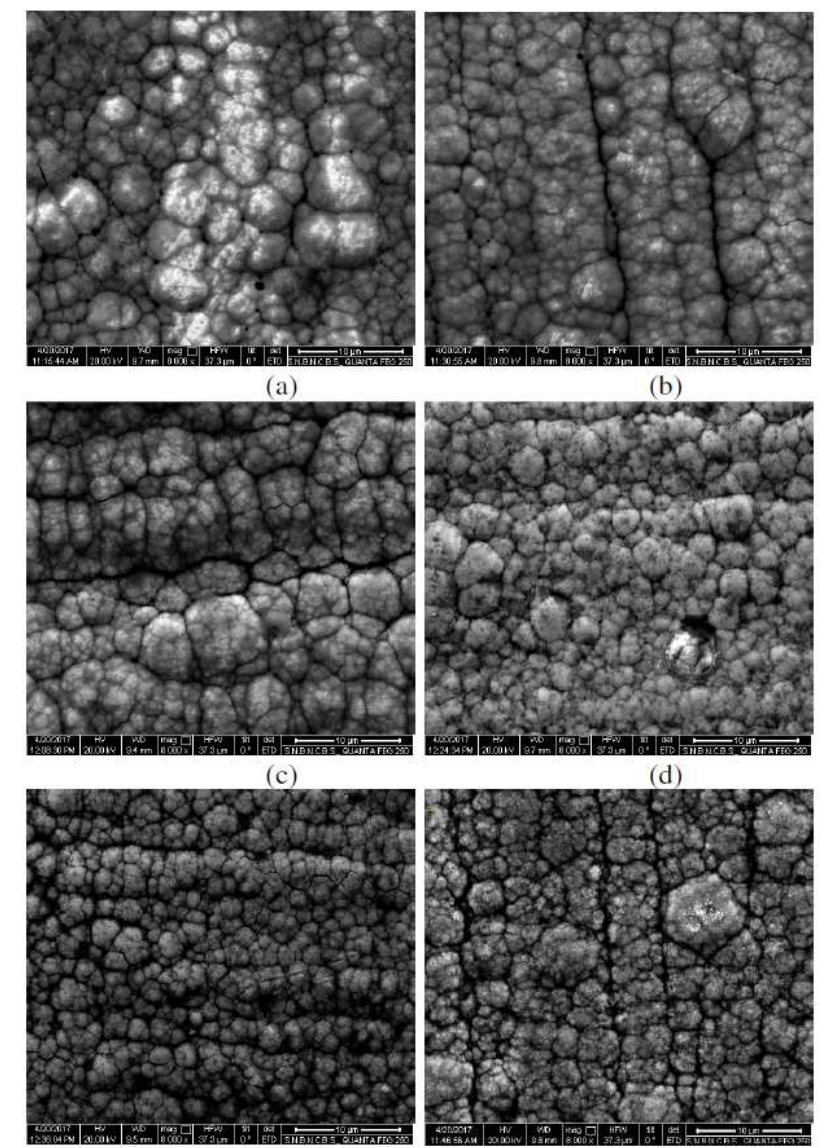

(e)

(f)

Figure 3. SEM micrographs of Ni-B-W-Mo coatings (a) as-deposited and heat treated at (b) $300{ }^{\circ} \mathrm{C}$, (c) $350{ }^{\circ} \mathrm{C}$, (d) $400{ }^{\circ} \mathrm{C}$, (e) $450{ }^{\circ} \mathrm{C}$ and (f) $500{ }^{\circ} \mathrm{C}$, for 1 hour.

\section{Phase transformations}

To study the phase transformations, XRD of the as-deposited and heat-treated coatings were carried out, and the results are shown in Fig. 5. The as-deposited coatings are amorphous, which contradicts the deposited low-B content. The inclusion of high amounts of $\mathrm{W}$ into Ni-B coatings promotes the amorphous phase, which is possibly the reason why the coatings are amorphous, even though they lie in the low-B range [23]. On heat treatment at $300 / 350{ }^{\circ} \mathrm{C}$, for 1 hour, $\mathrm{Ni}_{3} \mathrm{~B}$ phases appear. Above $350{ }^{\circ} \mathrm{C}$, additional $\mathrm{Ni}_{2} \mathrm{~B}$ phases appear. Up to a heat treatment temperature of $400{ }^{\circ} \mathrm{C}$, the amorphous hump could still be observed (Fig. 5). This is an indication of a rise in the coatings crystallization temperature. 
Similar results have been also reported for Ni-B-W coatings with high-W and low-B contents [23]. The formation of borides has been also reported for the heat treatment of Ni-B, Ni-B-W and Ni-B-Mo coatings [13, 17-18]. With the heat treatment, the reflection from the face centered cubic $\mathrm{Ni}$ (111) increases, especially at $450 / 500{ }^{\circ} \mathrm{C}$. W and Mo solubility limits in $\mathrm{Ni}$ are 39 and $38 \mathrm{wt} . \%$, respectively, and hence, they are present in a solid solution form [20]. Such results are also confirmed from the XRD results (Fig. 5), since no W or Mo phases could be observed. No oxide phases could be observed at $500{ }^{\circ} \mathrm{C}$, although the coating turned bluish (possibly due to $\mathrm{NiO}$ ), but they can be revealed from further XPS studies.

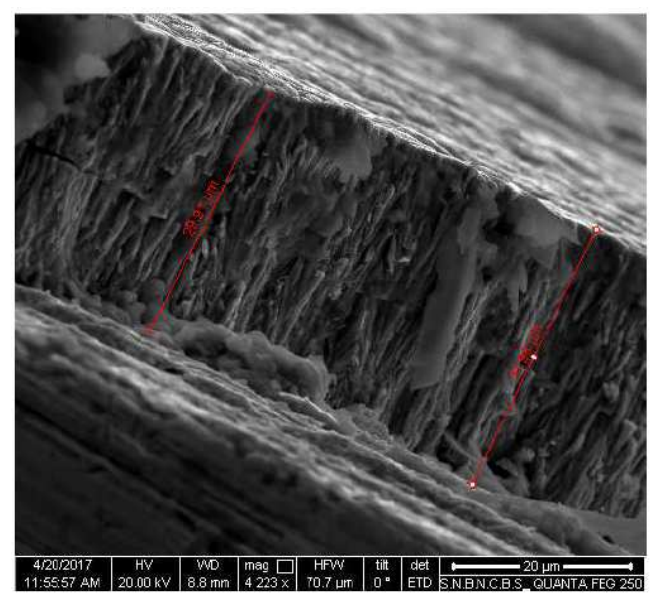

Figure 4. Cross cut section of the as-deposited Ni-B-W-Mo coating.

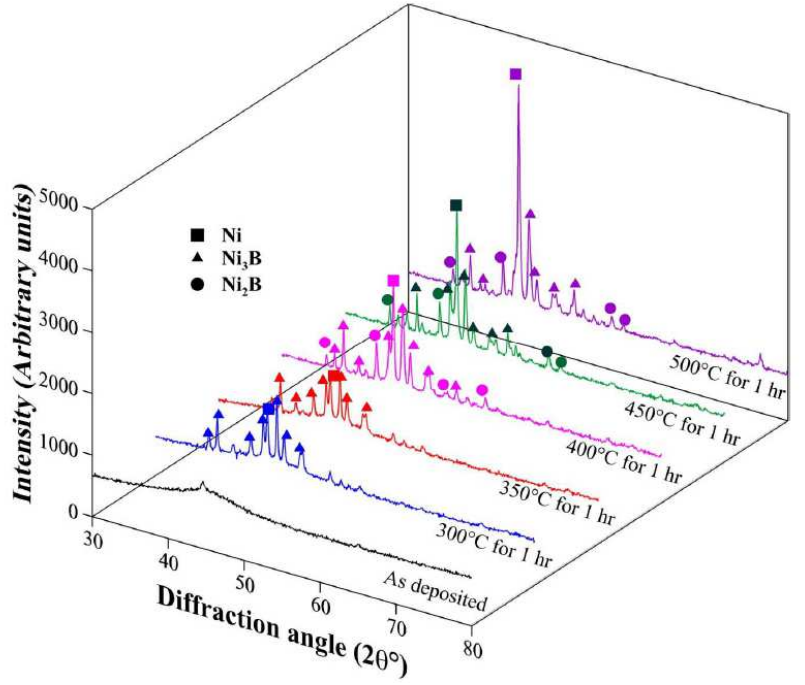

Figure 5. XRD of as-deposited and heat-treated electroless Ni-B-W-Mo coatings.

\section{Electrochemical Impedance Spectroscopy}

The coatings corrosion resistance was studied using EIS in $3.5 \% \mathrm{NaCl}$, and the Nyquist plot is presented in Fig. 6.

The corresponding EIS parameters are displayed in Table 1. It can be clearly observed, in Fig. 6(a), that the coatings heat-treated at $500{ }^{\circ} \mathrm{C}$ have the highest corrosion resistance, with a big semi-circular loop in the high frequency region. $\mathrm{R}_{\mathrm{ct}}$ and $\mathrm{C}_{\mathrm{dl}}$ values (Table 1) also indicate the same. A high $\mathrm{R}_{\mathrm{ct}}$ and low $\mathrm{C}_{\mathrm{dl}}$ are 
indicative of higher corrosion resistance, as observed for the coatings heat-treated at $500{ }^{\circ} \mathrm{C}$, in Table 1 . This is even comparable to those observed for high corrosion resistant Ni-P coatings and its variants [19], as well as for the binary $\mathrm{Ni}-\mathrm{B}$ variants [14]. The high corrosion resistance of Ni-B-W-Mo coatings heattreated at $500{ }^{\circ} \mathrm{C}$ may be attributed to the formation of a protective oxide layer, and to $\mathrm{W}$ inter-diffusion from the coating to the surface, through the grain boundaries, after subjecting them to a high temperature treatment [17]. Moreover, it has also been observed, in electroless Ni-B-W, as well as in Ni-BMo coatings, that the corrosion resistance improves after the heat treatment, which agrees well with the present work [17-18]. The as-deposited and heattreated coatings, at $300-450{ }^{\circ} \mathrm{C}$, exhibit a semi-circular loop in the high frequency region, and a loop in the low frequency region (Fig. 6(b)), in the Nyquist plot. This is indicative of a physicochemical phenomenon occurring at the metal/coating/solution interface [24]. Similar results have been reported for electroless Ni-low B coatings [14].

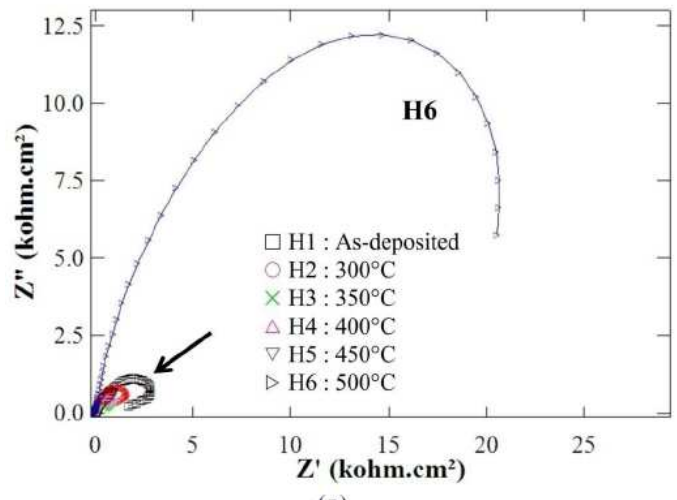

(a)

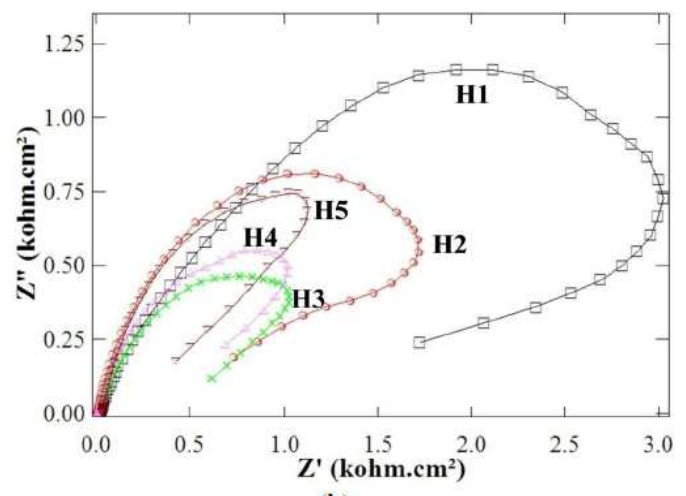

(b)

Figure 6. Nyquist plots of Ni-B-W-Mo coatings: (a) as-deposited and heat-treated at $300-500{ }^{\circ} \mathrm{C}(\mathrm{H} 1-\mathrm{H} 6)$ and (b) as-deposited and heat-treated at 300-450 ${ }^{\circ} \mathrm{C}(\mathrm{H} 1-\mathrm{H} 5)$, indicated by an arrow in (a).

Table 1. EIS parameters of electroless Ni-B-W-Mo coatings.

\begin{tabular}{ccc}
\hline Heat treatment condition & $\mathbf{R}_{\mathbf{c t}}\left(\mathbf{\Omega . c m} \mathbf{c m}^{\mathbf{}}\right)$ & $\mathbf{C}_{\mathbf{d l}}(\boldsymbol{\mu} \mathbf{F})$ \\
\hline H1 (As-deposited) & 3662.00 & 138.6 \\
$\mathrm{H} 2\left(300^{\circ} \mathrm{C}\right)$ & 2197.00 & 178.3 \\
$\mathrm{H} 3\left(350^{\circ} \mathrm{C}\right)$ & 1492.00 & 437.6 \\
$\mathrm{H} 4\left(400^{\circ} \mathrm{C}\right)$ & 1531.00 & 801.6 \\
$\mathrm{H} 5\left(450^{\circ} \mathrm{C}\right)$ & 1723.00 & 577.1 \\
H6 $\left(500^{\circ} \mathrm{C}\right)$ & 28513.00 & 70.06 \\
\hline
\end{tabular}

The phase plot ( $\log f$ vs. theta) in Fig. 7 clearly reveals a single phase angle maximum for the coating heat-treated at $500{ }^{\circ} \mathrm{C}$, for 1 hour, with high corrosion resistance. In general, a two phase angle maximum suggests the involvement of two time constants, and may be related to electrolyte/coating and coating/substrate interfaces. Thus, it may be concluded from the loop in the high frequency region and in the single phase angle maximum, in Fig. 6 and Fig. 7, respectively, that, except for the coating heat-treated at $500{ }^{\circ} \mathrm{C}$, for 1 hour, the electrolyte may have penetrated into the substrate, for as-deposited and heat- 
treated coatings. A coating corrosion resistance depends, to a large extent, on the coating thickness, porosity, morphology, internal stresses, grain size, etc. In the present case, though relatively high thickness of the coatings is achieved, the electrolyte still penetrates, in the as-deposited, as well as in the $300-450{ }^{\circ} \mathrm{C}$ coatings cases. This happens due to the columnar growth [14] in the as-deposited condition, and it is further aided by the formation of new phases (that form local corrosion cells with different potentials), grain growth and creation of grain boundaries with the heat treatment [13]. Furthermore, the heat treatment at 500 ${ }^{\circ} \mathrm{C}$ results in $\mathrm{W}$ diffusion through the grain boundaries to the surface, which forms a protective oxide layer, thereby preventing corrosion [17].

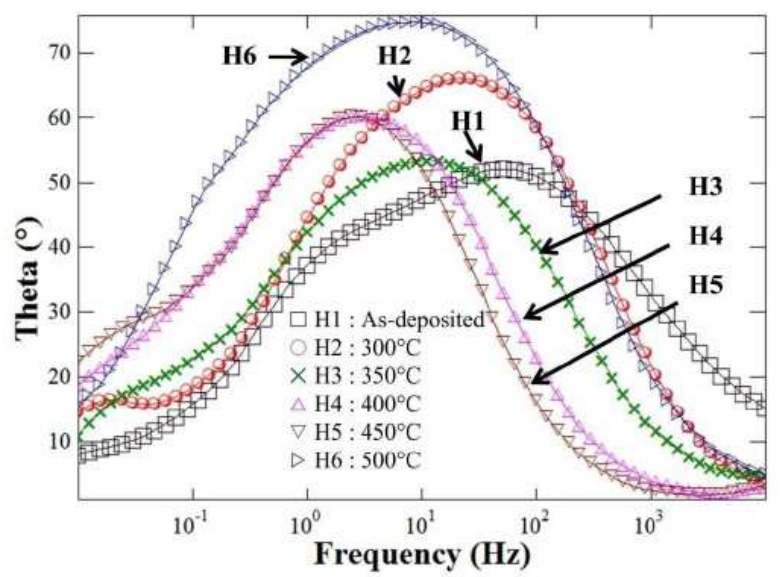

Figure 7. EIS phase plot of electroless Ni-B-W-Mo coatings. H1 to H6 indicates the coatings in as-deposited and $500{ }^{\circ} \mathrm{C}$ heat-treated conditions, respectively.
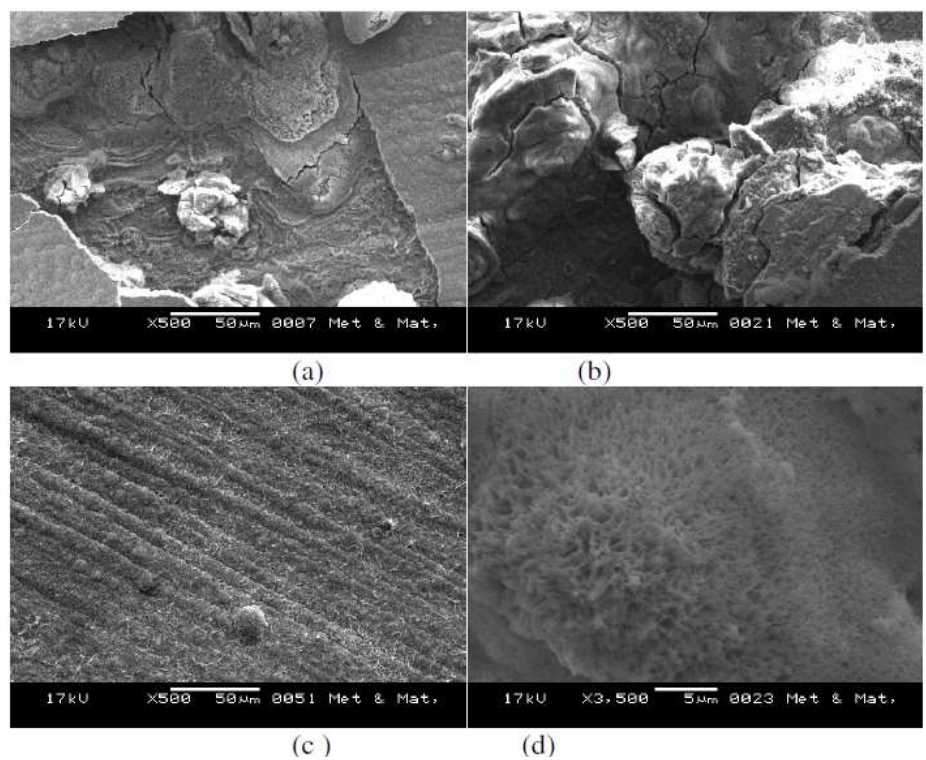

Figure 8. SEM micrographs of coatings after EIS in 3.5\% NaCl: (a) as-deposited (b), heat treated at $350{ }^{\circ} \mathrm{C}$, (c) heat treated at $500{ }^{\circ} \mathrm{C}$ and (d) magnified view of (c).

\section{Corrosion mechanism}

The coatings' corrosion mechanism is further assessed from SEM micrographs of some of the specimens subjected to EIS, and is shown in Fig. 8. 
The as-deposited electroless Ni-B-W-Mo coating (Fig. 8(a)) indicates the formation of local cracks and of some black spots. The coating heat-treated at $350{ }^{\circ} \mathrm{C}$, for 1 hour, also reveals significant cracking, as well as a severe attack by chloride ions (Fig. 8(b)). The electrolyte, therefore, penetrates through the coating, as previously mentioned, and the formation of localized cells is confirmed from Fig. 8(a) and Fig. 8(b). Due to the formation of such corrosion pits, $\mathrm{C}_{\mathrm{dl}}$ deteriorates (Table 1). Electroless Ni-B-W-Mo coatings, heat-treated at $500{ }^{\circ} \mathrm{C}$ for 1 hour, do not show such severe cracks, (Fig. 8(c)), which is in accordance with the EIS results (Table 1). Instead, the formation of a corrosion product with a specific nanostructure may be identified in its magnified view (Fig. 8(d)). This is similar to the observation made by Bekish et al. [25]. The formation of such films may prove to be beneficial for the coatings, thereby improving their corrosion resistance. Therefore, the corrosion resistance of Ni-BW-Mo coatings heat-treated at $500{ }^{\circ} \mathrm{C}$ is enhanced, due to two reasons: (a) W diffusion to the surface through grain boundaries or nodules and (b) formation of a new corrosion protection film.

Finally, it may be also concluded that $\mathrm{W}$ and Mo inclusion, as well as the heat treatment at $500{ }^{\circ} \mathrm{C}$, result in an excellent corrosion resistance of Ni-B coatings. It has been mostly observed that hypophosphite reduced coatings are highly corrosion resistant, in comparison to borohydride reduced variants. The borohydride reduced coatings are mainly preferred for their high hardness and anti-wear/friction properties. The present study thus opens the coatings scope for applications also requiring enhanced corrosion resistance. It may be also herein noted that an electroless Ni-B bath containing only sodium tungstate $(25 \mathrm{~g} / \mathrm{L})$ led to $\sim 3.5 \% \mathrm{~W}$ deposition, while sodium molybdate $(25 \mathrm{~g} / \mathrm{L})$ inclusion only led to $\sim 4.1 \%$ Mo deposition [3]. When both of them are simultaneously present in the coating bath, W deposition is remarkably improved, which proves to be beneficial for the coatings properties. Therefore, it is necessary to further study the quaternary bath chemistry, which could lead to the discovery of the borohydride reduced coatings overwhelming properties.

\section{Conclusions}

A quaternary variant of sodium borohydride reduced coating, containing $\mathrm{W}$ and Mo, was deposited on AISI 1040 steel. The following conclusions may be drawn from this study:

a) The deposited quaternary coatings lie in the low B range, with $3.2 \mathrm{wt} . \% \mathrm{~B}$ in the coatings, while the achieved $\mathrm{W}$ content is quite high, i.e., 15.7 wt. $\%$. Such high $\mathrm{W}$ content is observed when sodium molybdate is present, along with sodium tungstate, in the borohydride reduced electroless bath.

b) The as-deposited and heat-treated coatings exhibited a well defined nodular structure. The formation of grain boundaries was observed when the coatings were heat-treated.

c) Electroless Ni-B-W-Mo coatings are amorphous in an as-deposited condition. But, due to the low B content, it was expected that the coatings were nanocrystalline. The high $\mathrm{W}$ content promotes the amorphous phase in an as- 
deposited condition. Heat treatment at $300-500{ }^{\circ} \mathrm{C}$, for 1 hour, resulted in the precipitation of crystalline $\mathrm{Ni}, \mathrm{Ni}_{3} \mathrm{~B}$ and $\mathrm{Ni}_{2} \mathrm{~B}$ phases, while $\mathrm{W}$ and $\mathrm{Mo}$ are present in the coatings, in a solid solution state.

d) EIS studies in $3.5 \% \mathrm{NaCl}$ indicate corrosion resistance degradation after heat treatment at $300-450{ }^{\circ} \mathrm{C}$, in comparison to the as-deposited coatings. This is attributed to the formation of local cells, and to the penetration of the electrolyte through defects such as grain boundaries, as well as columnar growths. Concerning heat treatment, at a further higher temperature of 500 ${ }^{\circ} \mathrm{C}$, for 1 hour, a significant improvement in corrosion resistance was achieved. This happens due to the aggravation of $\mathrm{W}$ diffusion through the grain boundaries to the coating surface, at higher heat treatment temperatures, and to the formation of a protective oxide layer. The SEM micrograph also shows a thin film of corrosion product, which inhibits the $500{ }^{\circ} \mathrm{C}$ heat-treated coating corrosion.

\section{Acknowledgement}

The authors gratefully acknowledge the assistance of DST, PURSE-II program and COE, TEQIP-II program of Jadavpur University.

\section{References}

1. Sudagar J, Lian J, Sha W. Electroless nickel, alloy, composite and nano coatings - A critical review. J Alloy Compd. 2013;571:183-204.

2. Mukhopadhyay A, Barman TK, Sahoo P. Effect of operating temperature on tribological behavior of as-plated Ni-B coating deposited by electroless method. Tribol. Trans. 2018;61:41-52.

3. Mukhopadhyay A, Barman TK, Sahoo P. Tribological behavior of sodium borohydride reduced electroless nickel alloy coatings at room and elevated temperatures. Surf Coat Technol. 2017;321:464-476.

4. Bülbül F, Altun H, Ezirmik V, et al. Investigation of structural, tribological and corrosion properties of electroless Ni-B coating deposited on 316L stainless steel. Proc IMechE, Part J: J Eng Tribol. 2017;227:629-639.

5. Çelik İ, Karakan M, Bülbül F. Investigation of structural and tribological properties of electroless Ni-B coated pure titanium. Proc IMechE, Part J: J Eng Tribol. 2016;230:57-63.

6. Kanta AF, Vitry V, Delaunois F. Effect of thermochemical and heat treatments on electroless nickel-boron. Mater Lett. 2009;63:2662-2665.

7. Vitry V, Kanta AF, Delaunois F. Application of nitriding to electroless nickel-boron coatings: Chemical and structural effects; mechanical characterization; corrosion resistance. Mater Des. 2012;39:269-278.

8. Dervos CT, Novakovic J, Vassiliou P. Vacuum heat treatment of electroless Ni-B coatings. Mater Lett. 2004;58:619-623.

9. Niksefat V, Ghorbani M. Mechanical and electrochemical properties of ultrasonic-assisted electroless deposition of $\mathrm{Ni}-\mathrm{B}-\mathrm{TiO}_{2}$ composite coatings. J Alloy Compd. 2015;633:127-136. 
10. Ghaderi $\mathrm{M}$, Rezagholizadeh $\mathrm{M}$, Heidary $\mathrm{A}$, et al. The effect of $\mathrm{Al}_{2} \mathrm{O}_{3}$ nanoparticles on tribological and corrosion behavior of electroless $\mathrm{Ni}-\mathrm{B}-$ $\mathrm{Al}_{2} \mathrm{O}_{3}$ composite coating. Prot Met Phys Chem Surf. 2016;52:854-858.

11. Georgiza E, Gouda V, Vassiliou P. (2017). Production and properties of composite electroless Ni-B-SiC coatings. Surf Coat Technol. 2017. DOI: 10.1016/j.surfcoat.2017.06.019.

12. Wang ZC, Yu L, Qi ZB, et al. Electroless nickel-boron plating to improve the corrosion resistance of magnesium $(\mathrm{Mg})$ alloys. Corrosion Prevention of Magnesium Alloys, Woodhead Publishing Limited; 2013. pp 370-392.

13. Anik M, Körpe E, Şen E. Effect of coating bath composition on the properties of electroless nickel-boron films. Surf Coat Technol. 2008;202:1718-1727.

14. Baskaran I, Sankara Narayanan TSN, et al. Corrosion resistance of electroless Ni-low B coatings. Trans. IMF. 2009;87:221-224.

15. Hamid ZA, Hassan HB, Attyia AM. Influence of deposition temperature and heat treatment on the performance of electroless Ni-B films. Surf Coat Technol. 2010;205:2348-2354.

16. Das SK, Sahoo P. Electrochemical impedance spectroscopy of Ni-B coatings and optimization by Taguchi method and grey relational analysis. Port Electrochim Acta. 2011;29:211-231.

17. Yildiz RA, Göksenli A, Yüksel BH, et al. Effect of annealing temperature on the corrosion resistance of electroless produced Ni-B-W coatings. Adv Mater Res. 2013;651:263-268.

18. Serin I, Göksenli A, Yüksel B, et al. Effect of Annealing Temperature on the Corrosion Resistance of Electroless Ni-B-Mo Coatings. J Mater Eng Perform. 2015;24:3032-3037.

19. Balaraju JN, Selvi VE, Grips VW, et al. Electrochemical studies on electroless ternary and quaternary $\mathrm{Ni}-\mathrm{P}$ based alloys. Electrochim Acta. 2006;52:1064-1074.

20. Balaraju JN, Raman N, Manikandanath NT. Nanocrystalline electroless nickel poly-alloy deposition: incorporation of $\mathrm{W}$ and Mo. Trans. IMF. 2014;92:169-176.

21. Vitry V, Sens A, Kanta AF, et al. Experimental study on the formation and growth of electroless nickel-boron coatings from borohydride-reduced bath on mild steel. Appl Surf Sci. 2012;263:640-647.

22. Mukhopadhyay A, Barman TK, Sahoo P. Effects of heat treatment on tribological behavior of electroless $\mathrm{Ni}-\mathrm{B}$ coating at elevated temperatures. Surf Rev Lett. 2017;24:1850014.

23. Drovosekov AB, Ivanov MV, Krutskikh VM, et al. Chemically deposited Ni-W-B coatings: composition, structure, and properties. Prot Met. 2005;41:55-62.

24. Kanta AF, Poelman M, Vitry V, et al. Nickel-boron electrochemical properties investigations. J Alloy Compd. 2010;505:151-156.

25. Bekish YN, Poznyak SK, Tsybulskaya LS, et al. Electrodeposited Ni-B alloy coatings: Structure, corrosion resistance and mechanical properties. Electrochim Acta. 2010;55:2223-2231. 